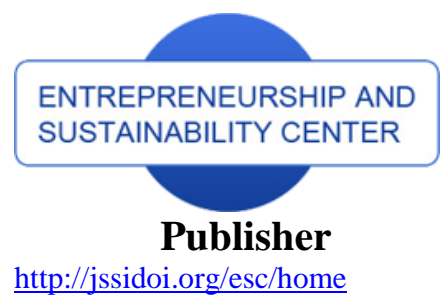

$\underline{\text { http://jssidoi.org/esc/home }}$

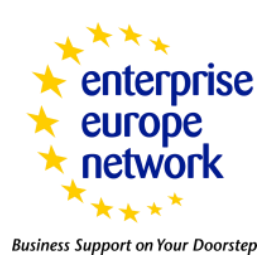

CASPA

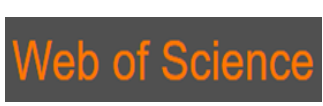

1) Clarivate

\title{
IDENTIFICATION OF THE FACTORS OF COMPETITIVENESS OF INDUSTRIAL COMPANY BASED ON THE MODULE APPROACH
}

\author{
Boris N. Gerasimov ${ }^{1}$, Vera A. Vasyaycheva ${ }^{2}$, Kirill B. Gerasimov ${ }^{3}$ \\ ${ }^{I}$ Samara University of Public Administration «International Market Institute», \\ 21, G.S. Aksakova Str., Samara, 443030, Russian Federation \\ ${ }^{2,3}$ Samara National Research University, 34, Moscovskoe shosse, Samara, 443086, Russian Federation \\ E-mails: ${ }^{1}$ boris0945@mail.ru; ${ }^{2}$ veraavasyaycheva@yandex.ru; ${ }^{3}$ 270580@bk.ru
}

Received 10 July 2018; accepted 10 October 2018; published 30 December 2018

\begin{abstract}
The purpose of the work is to present the results of studying the factors of competitiveness of the companies of transport machine building of Russia by segmentation on the basis of the module approach. The research consists in analyzing the modern developments in the sphere of managing the competitiveness of industrial companies in economic systems. Materials of the reports on global competitiveness were used. The research is based on the recent tendencies in the sphere of systematization of competitiveness factors of industrial companies. Based on the performed research, the main factors of competitiveness of industrial companies are systematized by segmentation on the basis of the module approach. Each module is assigned with blocks that determine qualitative and qualitative characteristics of their production activities, as well as indicators that allow evaluating the factors of competitiveness of companies of Russian transport machine building. Scientific significance of the received results consists in development of theoretical \& methodological and practical aspects of managing the competitiveness of industrial company in the modern conditions. The research results are a certain volume of knowledge increase, which allow solving a range of scientific tasks and are a theoretica basis for further research in the sphere of increase of competitiveness of companies of transport machine building on the basis of the module approach by applying the presented scientific solutions and tools.
\end{abstract}

Keywords: company; competitiveness; factors; module approach; transport machine building; innovative activities

Reference to this paper should be made as follows: Gerasimov, B.N.; Vasyaycheva, V. A.; Gerasimov, K.B. 2018. Identification of the factors of competitiveness of industrial company based on the module approach, Entrepreneurship and Sustainability Issues 6(2): 677-691. http://doi.org/10.9770/jesi.2018.6.2(15)

JEL Classifications: L62, O32, P42

\section{Introduction}

Against the background of existing means and methods of managing the competitiveness of industrial companies, modern approaches are measures with development of companies and external conditions of their functioning. By now, a company has become complicated as to the structure of functions and the style of relations, as to the structure of functions, and as to the style of relations between employees of various levels of management; there's 
a tendency for growth of the number of managers, with increased requirements to competence of personnel. Active behavior of company in competitive environment destroys traditional methods and style of management. Large companies appear, and small companies function successfully.

Observing the companies that achieve success in modern Russia, it is possible to state that this is due to the fact that there's an adequate concept of management of competitiveness, which is capable of ensuring high efficiency, effectiveness, and dynamics of production. New organizational behavior is formed, which ensures flexibility of the market, and, therefore, successful functioning of the company. The general tendency of change of traditional management consists in transition from ,supporting practice“ of activities to ,development“, formation of innovations-active strategy of behavior in the market, which stimulates forecasting and quick reaction to changeability of external environment.

Very often - both in theory and practice of management of modern industrial companies - attention is paid to the level of their innovative activity. Innovative activity is seen as a direction of activities that increases the probability of successful functioning of a company. It reflects the measure of establishment of company's positions in the market and is a basis of increase of its competitiveness level (Zhu \& Cheung, 2017).

In industry, innovative activity is traditionally linked to the level of implementing new product and progressive technology, which are assesses according to the special methodology, and top-priority directions of development of domestic and global science. Creation of new highly-effective technologies depends on development of fundamental research. It should be noted that the level of elaboration of the problem of managing the competitiveness of industrial companies in the conditions of market economy is insufficient: there's no comprehensive approach to determining this category, methods of its evaluation, and peculiarities of management.

\section{Materials and Method}

The issue of managing the competitiveness of industrial companies has remained one of the most complex issues over the recent decades. Now - in the crisis conditions - it has become the most important one. The level of development of domestic industrial companies and their competitive potential are not high enough. Such situation for industrial companies in the Russian economy is not satisfactory from the positions of large-scale plans of the country in the existing conditions of globalization. The issue of entering the leading positions is impossible without non-standard approaches to solving it.

According to the information from the Global Competitiveness Report, as of beginning of 2017 Russia was ranked 43rd among 138 positions. Planning of measures for increasing this ranking raises interest of the state to competitiveness of domestic industrial companies. Formation of the strategy of managing competitiveness consists in integration of objectively received information on potential development of organization in the shortterm as activation of using the innovational tools of management in the production process.

Competitiveness is treated as a feature of the object that is characterized by the level of real or potential satisfaction of specific consumer needs as compared to similar objects that are presented in the market (Kovalenko, 2013).

It should be noted that there's no common approach to defining the notion of competitiveness (Korotkov \& Eleneva, 2001; Kovalenko, 2013; Vasyaycheva, 2013):

- participants of the forum „European management forum“ define competitiveness as real or potential capability of company to sell the product that are more attractive for consumers than the rivals" products; 
- according to the Japanese scholar T. Kono, competitiveness of company is defined as a capability for implementing the set goals and innovational development for conquering the largest share of the market (Rasoul, 2009);

- the Russian economist N.S. Yashina thinks that competitiveness is a potential possibility for company's adaptation to the conditions of market competition (Gaynanov \& Guzairova, 2010);

- in the works (Ceptureanu, 2016; Netland \& Aspelund, 2013) competitiveness is defined as company's capability to withstand competition and to make competitive actions.

The notion of competitiveness at the micro-level is viewed by economists in various aspects:

- competitiveness of company as effectiveness of its production and sales activities in a certain market (Geras'kin \& Chkhartishvili, 2017);

- competitiveness of products as an essential difference from similar products for consumer choice (Abuzyarova, 2017).

It is possible to state that competitiveness of products determines competitiveness of the company - and, therefore, the sphere on the whole.

Let us view systemic characteristics of competitiveness by the example of companies of transport machine building of Russia. At the modern stage of innovational development of domestic industrial companies, the main issue is management of their competitiveness $(\mathrm{Kc})$. Over the whole life cycle, the company has to remain competitive and preserve positive economic effect (Sayganov \& Lensky, 2015).

For the purpose of identifying the factors Kc, the authors offer systematizing the main factors of competitiveness of industrial companies by their segmentation on the basis of the module approach (Figure 1).

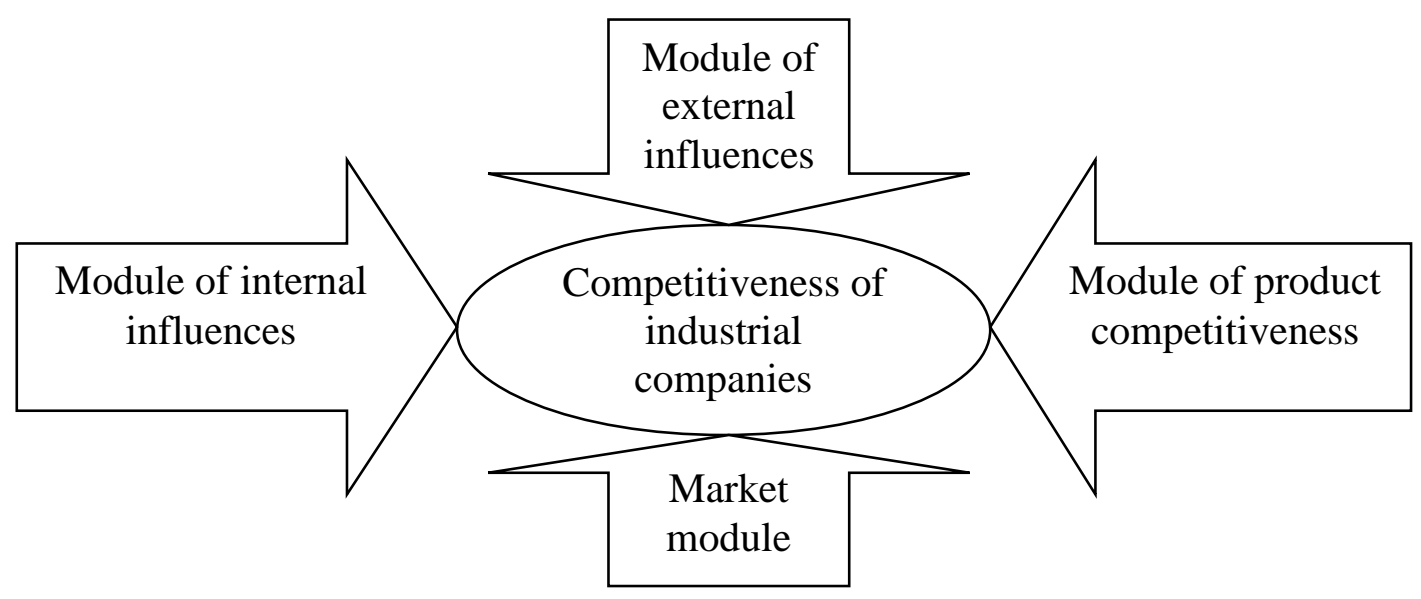

Figure 1. The module systematizaiton of factors of competitiveness of industrial companies

The module approach allows considering all deviations of the current level of competitiveness of companies from the ideal value and taking operative measures for eliminating them. The current level Kc consists of integral evaluations of the level of company's competitiveness according to these modules. 


\section{Module of external influences}

Evaluating the factors of influence of external environment on competitiveness of companies by analyzing the elements of the module of external influences, let us distinguish five main blocks that determine qualitative and quantitative characteristics of their production activities (Vasyaycheva, 2010):

1) territorial location of the company $-\varepsilon_{1}$;

2) industrial policy of the state $-\varepsilon_{2}$;

3) infrastructural provision of innovative activities $-\varepsilon_{3}$;

4) activities of the company in integration associations $-\varepsilon_{4}$;

5) rivals' having the innovational projects that are similar to the projects that are developed at the company $-\varepsilon_{5}$.

Territorial location of company near sources of raw materials, production of spare parts, and maintenance centers is one of the key factors that influence its Kc. Industrial policy of the state also belongs to the key factors of the module of external influences on competitiveness of companies of the basic sphere of transport machine building. It is based on the Constitution of the Russian Federation and is regulated by the Federal law "On national industrial policy in the Russian Federation" and "National complex program of development of machine building complex of Russia until 2020". The main purpose is implementation of state support for strategic integrated hightech productions, consolidations of resources of state and business, infrastructural provision of innovative activities of science-based companies, and leveling negative social consequences, which are the results of changes in the structure of industrial production.

The mechanisms of implementing the industrial policy in the sphere of transport machine building include:

- stimulation of manufacture of industrial products that conform to the requirements of the international market (Cetindamar \& Kilitcioglu, 2013);

- formation of state information and marketing structures that stimulates demand for products of the companies of transport machine building within the country and export;

- support for innovative activities of the companies of transport machine building;

- stimulating the creation of information and technological centers, business centers, and centers for supporting R\&D (Feurer \& Chaharbaghi, 1994);

- stimulation of reduction of time required for development and implementation of unique innovational projects (Khusainova \& Ustyuzhina, 2015);

- participation in development and creation of integrated science-driven business structures and industrial associations that manufacture competitive products;

- stimulating the development of sectorial interactions.

For quantitative evaluation of the factors of the module of external influences, let us use coefficients: $K_{\varepsilon_{k_{i}}}$ evaluation of factors of $\mathrm{k}$-th block $\varepsilon_{k}$ of module of $\mathrm{i}$-th company. The integral indicator of evaluation of factors of external environment is defined as linear dependence on $K_{\varepsilon_{k_{i}}}, \mathrm{i}=1,2,3,4,5$ of the form:

$$
K_{\varepsilon}=f\left(K_{\varepsilon_{1 i}}, K_{\varepsilon_{2 i}}, K_{\varepsilon_{3 i}}, K_{\varepsilon_{4 i}}, K_{\varepsilon_{5 i}}\right) \text {, }
$$


Evaluation of the factors of external environment is performed based on calculation of indicators that reflect the influence of industrial policy of the state (block $\varepsilon_{2}$ ) by determining the evaluations of the most significant factors of this block:

1) evaluation of support for innovative activities of $\boldsymbol{i}$ - th company:

$K_{\varepsilon_{2 i}}^{l}=\frac{V_{1 i}}{V_{2}}$

$V_{1 i}$ - volume of assets that are spent by the state for supporting innovative activities of i-th company; $V_{2}$ volume of assets that are spent by the state for supporting the sphere of transport machine building;

2) evaluation of stimulating the demand for products of transport machine building:

$K_{\varepsilon_{2}}^{2}=\frac{V_{3}}{V_{4}}$

$V_{3}$ - volume of subsidies that are spent by the state for purchasing the products of transport machine building; $V_{4}$

- volume of assets that are spent for purchasing the products of transport machine building;

3) evaluation of tax support for the company:

$K_{\varepsilon_{2 i}}^{3}=\frac{V_{5 i}}{V_{6 i}}$

$V_{5 i}$ - tax subsidies of $\boldsymbol{i}$ - th company; $V_{6 i}$ - total sum of taxes of $\boldsymbol{i}$ - th company;

4) integral indicator of evaluation of industrial policy of the state based on block $\varepsilon_{2}$ :

$K_{\varepsilon_{2 i}}=\frac{1}{3}\left(K_{\varepsilon_{2 i}}^{1}+K_{\varepsilon_{2 i}}^{2}+K_{\varepsilon_{2 i}}^{3}\right)$

The indicators of block $\left(\varepsilon_{4}\right)$ that evaluate the companies activities in integration associations are supplemented by the following ones:

1) $K_{\varepsilon_{4}}^{1}=\frac{I_{i n t, R F}}{I_{\text {all }, R F}}$ - indicator of significance of mutual flows in the RF;

2) $\quad K_{\varepsilon_{4}}^{2}=\frac{I_{i n t, C E S}}{I_{\text {all }, C E S}}$ - indicator of significance of mutual flows in common economic space;

3) $K_{\varepsilon_{4}}^{3}=\frac{e_{x}+i_{m}}{\mathrm{GDP}}$ - indicator of openness in product sale,

$I_{i n t, R F}$ - investments into issue of products of the company of transport machine building;

$I_{a l l, R F}$ - investments into issue of products of companies of the sphere of transport machine building of the RF

$I_{i n t, C E S}$ - investments into issue of products of the company of transport machine building;

$I_{\text {all,CES }}$ - investments into issue of products of companies of the sphere $\mathrm{v} e_{\mathrm{x}}$ - volume of export of products of transport machine building in countries of the integration association of common economic space; $i_{m}$ - volume of import of products of transport machine building from countries of integration association of single economic space; 
Growth of indicators means increase of the share of mutual flow - i.e., improvement of integration ties in the sphere (Nuruzzaman, 2015).

4) integral indicator based on the block of evaluation $\varepsilon_{4}$ of activities of the company in integration associations:

$$
K_{\varepsilon_{4 i}}=\frac{1}{3}\left(K_{\varepsilon_{4 i}}^{1}+K_{\varepsilon_{4 i}}^{2}+K_{\varepsilon_{4 i}}^{3}\right)
$$

The indicators on the basis of the fifth block $\left(\varepsilon_{5}\right)$ are as follows: $K_{\varepsilon_{5 i}}^{1}=0$, if the rivals have the similar projects; $K_{\varepsilon_{5 i}}^{1}=1$, if the rivals do not have the similar projects.

The integral indicator of the module of external influences is as follows:

$$
K_{\varepsilon}=\frac{1}{5}\left(K_{\varepsilon_{1 i}}+K_{\varepsilon_{2 i}}+K_{\varepsilon_{3 i}}+K_{\varepsilon_{4 i}}+K_{\varepsilon_{5 i}}\right) \text {, }
$$

where $K_{\varepsilon_{1 i}}$ and $K_{\varepsilon_{3 i}}$ are evaluated by experts. All indicators are normed, $0 \leq K_{\varepsilon} \leq 1$.

\section{Market module}

In its turn, competitive market dictates the requirement of precise determination of the vector of development of economic system. Evaluating the influence of the market module on competitiveness of the company of transport machine building, let us distinguish five main blocks:
1) marketing potential of company $-M_{1}$;
2) share of company in the global market $-M_{2}$;
3) share of company in the internal market $-M_{3}$;
4) share of potential rivals in the market $-M_{4}$;
5) goodwill of company $-M_{5}$.

For calculating the indicators that characterize Kc of company based on the market module, we consider that $K_{M}=f\left(K_{M_{1 i}}, K_{M_{2 i}}, K_{M_{3 i}}, K_{M_{4 i}}, K_{M_{5 i}}\right), 0 \leq K_{M} \leq 1$.

where $K_{M_{k i}}$ - evaluation of the factors of k-th block of module $M_{k}$ of i-th company.

$K_{M_{2 i}}$ - share of $\mathrm{i}$ - th company in the global market;

$K_{M_{3 i}}$ - share of $\mathrm{i}$ - th company in the internal market;

$K_{M_{4 i}}$ - share of rivals of $\mathrm{i}$-th company in the global market;

$K_{M_{4 i}}^{\prime}$ - share of rivals of $\mathbf{i}$-th company in the internal market;

$K_{M_{2 i j}}$ - share of $\mathrm{j}$-th rival of $\mathrm{i}$-th company in the global market;

$K_{M_{3 i j}}$ - share of $\mathrm{j}$ - th rival of $\mathrm{i}$ - th company in the internal market; 
$K_{M_{5 i}}\left(H H I_{\text {int }}\right)$ - Herfindahl-Hirschman Index for the internal market;

$K^{\prime}$

$M_{5 i}($ HHIext $)$ - Herfindahl-Hirschman Index for the global market;

Marketing potential of the company is function on the factors of the market module

$K_{M_{1 i}}=f\left(K_{M_{2 i}}, K_{M_{3 i}}, K_{M_{4 i}}, K_{M_{5 i}}\right)$,

and depends on the value of indicators of other three modules. Its evaluation is performed on the basis of the calculated coefficients.

$$
\begin{aligned}
& K_{M_{2 i}}=\frac{v_{1 i}}{v_{2}}, i=\overline{1,7} ; \quad K_{M_{3 i}}=\frac{v_{3 i}}{v_{4}}, i=\overline{1,7} ; \quad K_{M_{4 i}}=\sum_{j=1}^{6} K_{M_{2 i j}} ; i=\overline{1,7} ; \\
& K_{M_{4 i}}^{\prime}=\sum_{j=1}^{6} K_{M_{3 i j}} ; \quad K_{M_{5 i}}=H H I_{\mathrm{int}}=\sum_{i=1}^{7} K_{M_{3 i}}^{2} \cdot 100 \% \\
& K_{M_{5 i}}^{\prime}=H H I_{\text {ext }}=\sum_{i=1}^{7} K_{M_{2 i}}^{2} \cdot 100 \% .
\end{aligned}
$$

$v_{1 i}$ - volume of export products of i-th company;

$v_{2}$ - volume of products that are sold by the companies of the sphere in the global market;

$v_{3 i}$ - volume of products of the i-th company that are sold in the internal market;

$v_{4}$ - volume of products that are sold by the companies of the sphere in the internal market.

Herfindahl-Hirschman Index (HHI) is used for evaluating the level of monopolization of market, calculation of coefficient of concentration of the sphere's companies in it, and determination of the possibility for companies' integration. Monitoring of HHI allows the state to correct the pricing policy, determining the monopolists and preventing pricing conspiracy. The market could be divided into three categories:

1. $1,800 \leq \mathrm{HHI} \leq 10,000 \rightarrow$ high level of market monopolization which is peculiar for the companies with high level of goodwill and potential of development in the global market;

2. $1,000 \leq \mathrm{HHI} \leq 1,800 \rightarrow$ medium level of market monopolization, which is peculiar for the companies with medium level of goodwill, sufficient for effective functioning only in the market of the RF;

3. $\mathrm{HHI} \leq 1,000 \rightarrow$ low level of market monopolization, which is peculiar for the companies with low level of goodwill, which is insufficient for effective functioning in the conditions of competitive market.

\section{Module of internal influences}

The key direction in rationalization of organizational and technological structures of company is adequate evaluation of effectiveness for managing the company and development of managerial decisions for forecasting and increasing the indicators of effectiveness of functioning - primarily, economic. The following aspects are assessed (Sakhabieva, 2016):

- efficiency, which is manifested in the level of achievement of goals that are set before the company;

- skill of rational spending of material and financial resources, for full satisfaction of the needs of all structures and departments;

- achievement of optimal ratio of received economic results and costs in the process of production;

- level of influence of direct and indirect factors on the final result;

- position of the company in the market and availability of special methods of increasing the market share. 
In this aspect, the competitiveness of a company of transport machine building is influenced by internal factors: - quality of management (economic effectiveness of management, social effectiveness of management);

- effectiveness of financial and economic activities of company (financial sustainability, profitability, business activity, liquidity);

- investment attractiveness of company (investment potential, investment risk);

- innovative activity of company (profitability of investments into innovations, science intensity of products, profitability of innovational project);

- level of informatization of company (availability of information system of the company, IT infrastructure, complexes, and information frames);

- Kc of personnel (quality and quantity of personnel, effectiveness of management) (Orlova et al., 2016).

Evaluation of effectiveness of managing the companies of transport machine building is performed based on calculation of the indicators that reflect the influence of the factors of the third block:

1. Formation of the base of these companies of transport machine building for the long period (according to annual reports and electronic sources).

2. Execution of retrospective analysis of the companies of transport machine building for determining dynamics of their functioning.

3. Evaluation of dependence between the used resources and the result of production based on analysis of multiplicated production function.

4. Evaluation of allocative effectiveness of companies of transport machine building based on application of econometric analysis in view of the cost of final product (Sakhabieva, 2016).

5. Evaluation of technical effectiveness of companies of transport machine building with the DEA (Data Envelopment Analysis).

Evaluation of company's competitiveness is viewed from the point of view of effectiveness of technological processes and is performed in the aspect of comparison and analysis of companies as to the completeness of fullness and adequacy of using their resource (comparison of maximum issue of products with the set list of resources) or as to the level of effectiveness of distribution of resources (comparison of minimum spending of resources with the set volume of issue of products). In the first case, following the Farrell terminology, technical effectiveness of evaluated, and in the second case - structural or allocative effectiveness is evaluated. Technical and allocative effectiveness forms economic effectiveness of the company on the whole.

For evaluating technical effectiveness, the authors use the BCC model with variable feedback from the scale. Incoming parameters are as follows:

a. $\mathrm{x}_{1}$ - indicator of quality of company management, calculated based on the values of indicators of management effectiveness:

$x_{1}=\frac{\sum_{i=1}^{5} x_{1 i}}{5}$

$x_{11}=\frac{P_{p}}{E_{\text {man }}}-$ general indicator of effectiveness of management;

$x_{12}=\frac{E_{\text {man }}}{E_{g e n}}-$ indicator of managerial expenditures;

$x_{13}=\frac{N m a n}{N_{g e n}}-$ characteristics of the number of managerial personnel;

$x_{14}=\frac{E_{\operatorname{man}}}{Q}-$ indicator of significance of managerial expenditures; 
$x_{15}=\frac{E_{\text {eff }}}{E_{\text {man }}}$ - indicator of effectiveness of managerial expenditures;

$\Pi_{p}$ - profit for the studied period, $E_{\text {man }}$ - expenditures for management; Egen - general expenditures of the company; $N_{\text {man }}$ - number of managerial personnel; $N_{\text {gen }}$ - total number of company's employees; $Q$ - volume of issued products; $E_{\text {eff }}$ - economic effect for the analyzed period;

b. $\mathrm{x}_{2}$ - indicator of effectiveness of financial and economic activities of the company:

$x_{2}=\frac{\sum_{i=1}^{4} x_{2 i}}{4}$,

$x_{21}=\frac{A_{o w n}}{A_{b o r r}}$ - indicator of financial sustainability of the company (sustainability is acknowledged with $x_{2 i} \leq 0,7$ );

$x_{22}=\frac{N P_{p}}{A P_{p}}-$ indicator of company's profitability;

$x_{23}=\frac{N P_{p}}{E_{g e n}}$ - indicator of company's business activity;

$x_{24}=\frac{A_{t a}}{O_{c l}}$ - liquidity of company (optimal value is $x_{24} \in[0,7 ; 0,8]$ );

$A_{\text {own }}$ - company's own assets;

$A_{\text {borr }}$ - company's borrowed assets;

$N P_{p}$ - net profits;

$A P_{p}$ - average profits from selling net assets for the selected period;

$A_{t a}$ - cost of current turnover assets;

$O_{c l}$ - cost of current liabilities.

c. For evaluating the investment attractiveness of the company, it is offered to use SPACE analysis, which allows characterizing the company's functioning as to four directions, which assess internal potential and external environment, and determining the vector and strategy of its development.

4) $x_{4}$ - indicator of innovative activity of the company is calculated as

$x_{4}=\frac{\sum_{i=1}^{5} x_{4 i}}{5}$,

where $x_{41}=\frac{N_{v}}{N}$ - share of innovative products $\left(N_{v}\right)$ in the total volume of issue $(N)$;

$x_{42}=\frac{\left(R_{v}\right)_{\text {own }}}{R_{v}}-$ share of own innovational projects $\left(\left(R_{v}\right)_{\text {own }}\right)$ in the total volume of innovations $\left(R_{v}\right)$; 
$x_{43}=\frac{C_{v}}{C}$ - share of expenditures for development and implementation of the innovational project $\left(C_{v}\right)$ in the total volume of production costs of the company $(C)$;

$x_{44}=\frac{N P_{p}}{P_{i n v}}$ - profitability of investments into innovations $\left(P_{i n v}\right) ;$

$x_{45}=\frac{E_{R \& D}}{Q}$ - science intensity of production, $E_{R \& D}$ - expenditures for R\&D.

5) $\mathrm{x}_{5}$ - indicator Kc and quality of personnel are calculated with the methods of actuarial mathematics based on the system of key indicators (KPI).

For evaluating the allocative effectiveness, the authors view the model of technological process of the company of transport machine building as a multiplicative reflection of the type:

$$
Q=\alpha_{0} \prod_{i=1}^{n} x_{i}^{\alpha_{i}},
$$

where $Q$ - volume of issued products, $\alpha_{i}, i=\overline{1, n}$ - parameters of the model, $\mathrm{x}_{\mathrm{i}}, i=\overline{1, n}-$ set of resources (factors) that are included into the model, $\mathrm{n}$ - number of factors.

Parameters of the model, its adequacy, and significance of the model and factors are determined by econometric methods according to empirical data of the specific company.

Analysis of the production function, determined by formula (13), allows, on the one hand, determining the optimal ratio between consumer resources that ensure maximum result, and, on the other hand, evaluating allocative effectiveness of usage of resources with the set prices. Effectiveness of used resources is acknowledged in case of coincidence of final products with current prices for them.

For evaluating the allocative effectiveness of modern companies of transport machine building by studying the production function (13), totality of uncorrelated indicators that influence the competitive state and that are most statistically significant as a result of econometric analysis, is determined in the following way:

$Q=\alpha_{0} \prod_{i=1}^{6} x_{i}^{\alpha_{i}}$

$Q$ - revenues from selling products; $\mathrm{x}_{1}$ - labor cost at the company;

$\mathrm{x}_{2}$ - labor payment (personnel motivation); $\mathrm{x}_{3}$ - main production funds; $\mathrm{x}_{4}$ - expenditures for resources; $\mathrm{x}_{5}-$ investments into innovational projects. Parameters $\alpha_{i}, i=\overline{0,6}$ are determined by known econometric methods by linearization of the model.

\section{Module of product competitiveness}

The products that are issued by domestic companies of transport machine building possess a range of competitive deviations, which are obstacles for its entering the international market. In order to eliminate them, it is necessary to analyze, calculate, and forecast the main indicators of the module of competitiveness of the products as to quality and reliability, pricing, uniqueness, innovativeness, correspondence to international standards, and ecological performance. Quantitative analysis in this aspect is most effective.

Calculation of the indicators of products' competitiveness products is based on the model that ensures the complex systemic approach to analysis of the most significant factors of this module. The model was received on the basis of application of the methods of differential calculation of the function of several variables and is a 
reflection of a lot of factors of products' competitiveness on quality of results of company's activities - quality of products. The indicator of competitiveness of products $\mathrm{C}_{\text {prod }}$ is a function of several variables

$\mathrm{C}_{\text {prod }}=\mathrm{f}(\mathrm{p}, \mathrm{u}, \mathrm{v}, \mathrm{q}, \mathrm{s}, \mathrm{e})$,

$\mathrm{p}$ - price of products, $\mathrm{u}$ - uniqueness of products, $\mathrm{v}$ - innovativeness of products, $\mathrm{q}-$ quality and reliability of products, $\mathrm{s}$ - correspondence of products to international standards, $\mathrm{e}$ - ecological performance of products.

$\mathrm{C}_{\mathrm{prod}}=\mathrm{f}(\mathrm{p}, \mathrm{u}, \mathrm{v}, \mathrm{q}, \mathrm{s}, \mathrm{e}) \Rightarrow d K=\frac{\partial K}{\partial p} d p+\frac{\partial K}{\partial u} d u+\frac{\partial K}{\partial v} d v+\frac{\partial K}{\partial q} d q+\frac{\partial K}{\partial s} d s+\frac{\partial K}{\partial e} d e$

Or,

$$
\begin{gathered}
\frac{\partial K}{\partial p} d p=K_{1} ; \frac{\partial K}{\partial u} d u=K_{2} ; \frac{\partial K}{\partial v} d v=K_{3} ; \frac{\partial K}{\partial q} d q=K_{4} ; \frac{\partial K}{\partial s} d s=K_{5} ; \frac{\partial K}{\partial e} d e=K_{6}, \quad \Rightarrow \\
\Rightarrow \quad K_{\text {npod }}=K_{1}+K_{2}+K_{3}+K_{4}+K_{5}+K_{6} .
\end{gathered}
$$

$K_{i}, i=\overline{1,5}$ - increase of products' competitiveness, which depends on the corresponding factor. Considering all factors - save one - to be stable - let us study dependence of competitiveness on the variable factor.

1) $\frac{\partial K}{\partial p}$ - speed (indicator) of change of competitiveness depending on products“ price. As growth of prices reduces competitiveness, then

$$
\frac{d K_{1}}{d p}=-\alpha_{1} \frac{1}{p} \Rightarrow K_{1}=-\alpha_{1} \ln |p|+C_{1},
$$

where $\mathrm{C}_{1}-$ random constant (we consider that $\mathrm{C}_{1}=0$ ). Then,

$$
K_{1}=-\alpha_{1} \ln |p| \text {. }
$$

Relative share of products' price in the market $(\mathrm{p})$ is calculated as

$$
p=1-\frac{p_{\text {prod }}}{p_{\text {max }}}
$$

where $p_{\text {prod }}$ - price of the studied type of products, $\mathrm{p}_{\max }$ - maximum price of this type of products in the market. Similarly:

2) $\frac{\partial K}{\partial u}$ - speed (indicator) of change of competitiveness depending on uniqueness of products. Competitiveness of products is directly related to its uniqueness, so we have:

$$
\frac{d K_{2}}{d u}=\alpha_{2} u \Rightarrow K_{2}=\alpha_{2}\left(\frac{u^{2}}{2}+C_{2}\right) \Rightarrow K_{2}=\alpha_{2} \frac{u^{2}}{2} \text {. }
$$

Random variable $-\mathrm{C}_{2}=0$.

Relative share of unique products in the market $(\mathrm{u})$ is calculated as

$$
u=1-\frac{u_{\text {prod }}}{N}
$$

where $u_{\text {prod }}$ - number of types of unique products, $\mathrm{N}$ - total number of this type of products in the market. 
3) $\frac{\partial K}{\partial v}$ - speed (indicator) of change of competitiveness depending on innovativeness of products (direct dependence), so we have:

$$
\frac{d K_{3}}{d v}=\alpha_{3} v \Rightarrow K_{3}=\alpha_{3}\left(\frac{v^{2}}{2}+C_{3}\right) \Rightarrow K_{3}=\alpha_{3} \frac{v^{2}}{2} \text {. }
$$

Random variable $-\mathrm{C}_{3}=0$.

Relative share of innovative products in the market (v) is calculated as

$$
v=1-\frac{v_{\text {prod }}}{N} \text {, }
$$

where $\mathrm{v}_{\text {prod }}$ - number of types of innovative products, $\mathrm{N}$ - total number of these products in the market.

4) $\frac{\partial K}{\partial q}$ - speed (indicator) of change of competitiveness depending on quality of products (direct dependence):

$$
\frac{d K_{4}}{d q}=\alpha_{4} q \quad \Rightarrow \quad K_{4}=\alpha_{4}\left(\frac{q^{2}}{2}+C_{4}\right) \Rightarrow K_{4}=\alpha_{4} \frac{q^{2}}{2}
$$

Random constant $-\mathrm{C}_{4}=0$. Indicator of quality and reliability of products $(\mathrm{q})$ is calculated as:

$$
q=\frac{p_{\text {service }} n}{N},
$$

where $\mathrm{p}_{\text {service }}$ - price of service maintenance, $\mathrm{n}$ - total number of these products that passed service maintenance, $\mathrm{N}$ - total number of sold products of this type for the studied period.

5) $\frac{\partial K}{\partial s}$ - speed (indicator) of change of competitiveness depending on correspondence of products to international standards (direct dependence):

$$
\frac{d K_{5}}{d s}=\alpha_{5} s \quad \Rightarrow \quad K_{5}=\alpha_{5}\left(\frac{s^{2}}{2}+C_{5}\right) \Rightarrow K_{5}=\alpha_{5} \frac{s^{2}}{2} .
$$

Random constant $-\mathrm{C}_{5}=0$. Relative share of products that correspond to the international standards (s) is calculated as

$$
s=1-\frac{s_{\text {prod }}}{N},
$$

where $\mathrm{s}_{\mathrm{prod}}$ - number of types of products that correspond to the international standards, $\mathrm{N}$ - total number of these products in the market.

6) $\frac{\partial K}{\partial e}$ - speed (indicator) of measuring competitiveness depending on ecological performance of products to the standards (direct dependence):

$$
\frac{d K_{6}}{d e}=\alpha_{6} e \Rightarrow K_{6}=\alpha_{6}\left(\frac{e^{2}}{2}+C_{6}\right) \Rightarrow K_{6}=\alpha_{6} \frac{e^{2}}{2} \text {. }
$$

Random constant $-\mathrm{C}_{6}=0$. Relative share of ecological products (e) is calculated as

$$
e=1-\frac{e_{\text {prod }}}{N}
$$


where $\mathrm{e}_{\mathrm{prod}}$ - number of types of products that are potentially safe for the environment, $\mathrm{N}$ - total number of these products in the market.

Thus, we have:

$$
C_{\text {prod }}=-\alpha_{1} \ln |p|+\alpha_{2} \frac{u^{2}}{2}+\alpha_{3} \frac{v^{2}}{2}+\alpha_{4} \frac{q^{2}}{2}+\alpha_{5} \frac{s^{2}}{2}+\alpha_{6} \frac{e^{2}}{2},
$$

where $\alpha_{i}$ - coefficients of proportion, which evaluate significance of the influence of the corresponding factor on competitiveness of products, $0 \leq \alpha_{i} \leq 1$.

Value $C_{\text {prod }}$ of a competitive company should conform to the ratio: $0 \leq C_{\text {min }} \leq C_{\text {prod }} \leq C_{\text {max }} \leq 1$, values $C_{\text {min }}$ and $C_{\max }$ are determined as a result of analysis of the studied companies.

Calculated private indicators are normed, and their value is compared to the value of indicators of the leading company in each block, and conclusion on the direction of optimizing the company's activities is made.

\section{Conclusion}

One of the main problems of companies of the sphere is creation of sustainable and self-regulating system of management, which is aimed at effective usage of internal resources and stimulation of increase of rate of companies' development.

Crisis situations in economy led to the necessity for changing the institutional structure of industrial companies as the most important factors of innovational and organizational development of the sphere.

Identification of factors of competitiveness of industrial companies showed that a top-priority direction that allows stabilizing growth of effectiveness and increase of production quality is improvement of the existing mechanism of management of companies and its orientation at optimization of usage of the existing scientific and technical production potential.

\section{References}

Abuzyarova, M.I. (2017). Corporate innovation system management as a competitiveness factor: Methodological approaches. Espacios 38(12): 18. Retrieved from http://www.revistaespacios.com/a17v38n12/17381218.html

Ceptureanu, E.G. (2016). Considerations on competitiveness. Quality - Access to Success 17(155): 125-128.

Cetindamar, D. \& Kilitcioglu, H. (2013). Measuring the competitiveness of a firm for an award system. Competitiveness Review 23(1): 722. https://doi.org/10.1108/10595421311296597

Feurer, R. \& Chaharbaghi, K. (1994). Defining Competitiveness: A Holistic Approach. Management Decision 32(2): $49-58$. https://doi.org/10.1108/00251749410054819

Gaynanov D.A. \& Guzairova G.R. (2010). Economic and mathematical model of evaluating company's competitiveness. Bulletin of Ufa State Aviation Technical University 14(5): 243-246.

Geras'kin, M.I. \& Chkhartishvili, A.G. (2017). Analysis of game-theoretic models of an oligopoly market under constrains on the capacity and competitiveness of agents. Automation and Remote Control 78(1): 2025-2038. https://doi.org/10.1134/S000511791711008X 
The International Journal
ENTREPRENEURSHIP AND SUSTAINABILITY ISSUES

ISSN 2345-0282 (online) http://jssidoi.org/jesi/

2018 Volume 6 Number 2 (December)

http://doi.org/10.9770/jesi.2018.6.2(15)

Khusainova, S.V. \& Ustyuzhina, O.N. (2015). The essence and factors determining the competitive capacity of an enterprise. International Business Management 9(5): 848-855. Retrieved from http://medwelljournals.com/abstract/?doi=ibm.2015.848.855

Korotkov A.M. \& Eleneva Y.Y. (2001). Competitiveness of a company: approaches to provision, criteria, and methods of evaluation. Marketing in Russia and abroad 6.

Kovalenko A.I. (2013). Theoretical and methodological aspects of using the concept „,competitiveness“ in scientific studies. Modern competition 6(42): 65-79.

Netland, T.H. \& Aspelund, A. (2013). Company-specific production systems and competitive advantage: A resource-based view on the Volvo production system. International Journal of Operations and Production Management 33(11): 1511-1531. https://doi.org/10.1108/IJOPM-07-2010-0171

Nuruzzaman, M. (2015). Improving competitiveness in manufacturing-wholesaling-retailing supply chains. Advances in Business Marketing and Purchasing 22A: 221-457. https://doi.org/10.1108/S1069-096420150000022016

Orlova, L.V., Vasyaycheva, V.A., Sakhabieva, G.A. \& Pronina, N.N. (2016). Impact of Educational Attainment on the Development of Female Entrepreneurship in Kazakhstan. Indian Journal of Science and Technology 9(11): 89426-89433. Retrieved from http://www.indjst.org/index.php/indjst/article/view/89426

Rasoul, Shafaei (2009). An analytical approach to assessing the competitiveness in the textile industry. Journal of Fashion Marketing and Management: An International Journal 13(1): 20-36. https://doi.org/10.1108/13612020910939851

Sayganov, A.S. \& Lensky, A.V. (2015). Analysis of effectiveness of manufacture of crop research products in agricultural companies. Bulletin of the National Academy of Sciences of Belarus. Series „Agrarian Sciences" 1: 22-36. Retrieved from http://vesti.belal.by/vesti/pdf/20150103.pdf

Sakhabieva, G.A. (2016). The new generation of informatization systems overview. International Research Journal 6-1(48): 85-87.

Vasyaycheva, V.A. (2013). Preconditions of emergence and development of the strategy of managing the competitiveness of oil industry companies. Bulletin of State University of Management 16: 21-28.

Vasyaycheva, V.A. (2010). Increase of the level of competitiveness of companies of transport machine building on the basis of managing innovational projects. Samara: Published by Samara Humanitarian Academy.

Zhu, L. \& Cheung, S.O. (2017). Harvesting Competitiveness through Building Organizational Innovation Capacity. Journal of Management in Engineering 33(5): 04017020. https://doi.org/0.1061/(ASCE)ME.1943-5479.0000534 
Boris Nikiforovich GERASIMOV, doctor of Economics, Professor. Samara University of Public Administration «International Market Institute», department of Management, Russian Federation, 443030, Samara, 34 G.S. Aksakova str. ORCID ID: 0000-0001-6535-3569

Vera Ansarovna VASYAYCHEVA, candidate of Economics, associate Professor. Samara National Research University, department of Human Resources Management, Russian Federation, 443086, Samara, 34 Moscovskoe shosse.

ORCID ID: 0000-0002-5472-937

Kirill Borisovich GERASIMOV, candidate of Economics, associate Professor. Samara National Research University, department of Economics, Russian Federation, 443086, Samara, 34 Moscovskoe shosse.

ORCID ID: 0000-0001-6342-3076 